\title{
Jaipongan: Genre Tari Generasi Ketiga dalam Perkembangan Seni Pertunjukan Tari Sunda
}

\author{
Lalan Ramlan ${ }^{1}$ \\ Jurusan Tari, Sekolah Tinggi Seni Indonesia (STSI) Bandung
}

\begin{abstract}
ABSTRAK
Seni pertunjukan tari Sunda hingga saat ini telah diisi dengan tiga genre tari yang diciptakan oleh tiga tokoh pembaharu tari Sunda, yaitu Rd. Sambas Wirakusumah yang menciptakan genre tari Keurseus sekitar tahun 1920an, Rd. Tjetje Somantri yang menciptakan genre tari Kreasi Baru sekitar tahun 1950-an, dan Gugum Gumbira Tirasondjaya yang menciptakan genre tari Jaipongan pada awal tahun 1980-an. Ketiga genre tari tersebut memiliki citra estetiknya sendiri-sendiri sesuai latar budaya generasinya masing-masing. Genre tari Jaipongan yang kini sudah lebih dari 30 tahun belum tergantikan di dalamnya menunjukkan nilai-nilai yang mengakar dalam kehidupan masyarakat Sunda. Untuk mengekplanasi berbagai aspek penting yang melengkapi pembentukan sebuah genre tari ini digunakan metode kualitatif dengan pendekatan fenomenologi. Berdasarkan penelitian disimpulkan bahwa genre tari Jaipongan dibentuk oleh konsep dasar etika dan estetik egaliter dengan menghasilkan struktur koreografi yang simpel dan fleksibel yang terdiri dari empat ragam gerak, yaitu bukaan, pencugan, nibakeun, dan mincid.
\end{abstract}

Kata kunci: Gugum Gunbira, genre tari, dan Jaipongan

\section{ABSTRACT}

Jaipongan: The Genre of Third Dancing Generation in the Development of Sundanese Dance Performing Arts. Sundanese dancing performance art recently has been filled with three dancing genres created by three prominent reformers of Sundanese dances, namely Rd. Sambas Wirakusumah who created the dance genre of Keurseus around 1920, Rd. Tjetje Somantri who created the dance genre of Kreasi Baru (New Creation) 1950s, and Gugum Gumbira Tirasondjaya who created the dance genre of Jaipongan in the early 1980s. The three genres of the dances have their own aesthetic image based on their cultural background respectively. The Jaipongan dance genre which now has been more than 30 years and not yet been changed shows the values rooted in Sundanese community life. To explain various important aspects which complete the creation of a dance genre it applies qualitative method employing a phenomenological approach. Based on the research, it is concluded that Jaipongan dance genre is shaped by ethical and aesthetic concepts of egalitarian policies to produce a simple structure and flexible choreography of four modes of motion, i.e. aperture, pencugan, nibakeun, and mincid.

Keywords: Gugum Gunbira, dance genres, and jaipongan

\section{Pendahuluan}

Tari tradisional Sunda dalam perjalanannya mengalami perkembangan yang dinamis. Hal ini dapat diamati dari perubahan atau pergeseran nilai yang terjadi, yaitu dari media hiburan (kalangenan) menjadi media ekspresi estetik pertunjukan. Fenomena pergeseran nilai tersebut menjadi bahan diskursus tersendiri, terutama di kalangan akademisi seni tari. Lebih jauh, pembacaan terhadap tari tradisional Sunda sebagai seni pertunjukan mengacu pada momentum perubahan yang terjadi ketika media kalangenan para priyayi/menak Sunda yaitu Tayuban berubah menjadi sebuah genre tari yang disebut Keurseus.
Sejak itu, dinamika perkembangan seni pertunjukan tari Sunda hingga saat ini tercatat sudah melahirkan tiga generasi, yang sekaligus memunculkan tiga tokoh pembaharunya. Mereka adalah Rd. Sambas Wirakusumah yang melahirkan genre tari Keurseus pada kisaran masa akhir aristokrat feodalisme ( \pm tahun 1920-an). Ia melakukan pembakuan terhadap berbagai motif dan ragam gerak yang selalu disajikan oleh para pengibing dari kalangan priyayi/menak Sunda dalam arena Tayuban. Pembakuan ini sekaligus menghilangkan peran dan kehadiran ronggeng yang semakin bercitra negatif. Proses pembakuan tersebut pada akhirnya menghasilkan bentuk-

1 Alamat Korespondensi: Jurusan Tari - STSI Bandung, Jln. Buahbatu No. 212, Bandung, 40263. Tlp. (022) 7314982. Hp. 081572136195 email: lalanramlan74@yahoo.com 
bentuk penyajian tari tunggal putra dengan struktur koreografi yang terdiri atas ragam gerak pokok (sembahan, adeg-adeg, raras konda, jangkung ilo, gedut, pakbang, mincid, tindak tilu, engke gigir, santanaan, baksarai, mamandapan), ragam gerak penghubung (selut, galeong, lontang, cindek, dan tumpangtali), ragam gerak khusus (ungkleuktujuh), dan ragam gerak peralihan (gedig, mincid, keupat, trisi, raras, dan sirig). Segala atribut yang sudah biasa dikenakan oleh para pejabat bupati (priyayi) menak) Sunda masa itu menjadi kelengkapan busana tarinya, seperti pakaian takwa dan sinjang lereng atau motif lainnya dengan lipatan kain di ujung kanan (lamban) diletakkan di sebelah kanan, epek/stagen, sabuk, keris, tali bandang, dan bendo, kecuali soder/sampur. Digunakannya sampur/soder dalam menari karena properti ini sudah digunakan dalam menari sejak Tayuban masih populer di kalangan priyayilmenak Sunda masa lalu. Soder ini diberikan kepada penari oleh panitia juru baksa sebagai tanda giliran menari, terutama karena para penari/pengibing yang waktu itu adalah para pejabat (bupati) yang tentu saja tidak biasa membawa soder ke arena Tayuban. Beberapa repertoar tari yang tercatat pada masa itu adalah Lenyepan, Gawil, Kawitan, Gunungsari, dan Kastawa. Keseluruhan repertoar tari ini dikategorikan dalam genre tari Keurseus.

Setelah keberhasilan Rd. Sambas Wirakusumah dalam memulai babak modernisasi terhadap kesenian tradisional tari Sunda berjalan \pm 30 tahunan, lalu tercatat nama baru yang juga berlatar budaya priyayi/menak Sunda yaitu Rd. Tjetje Somantri pada kisaran masa awal kemerdekaan Negara R.I ( \pm tahun 1950-an). Ia berhasil menciptakan karya-karya tari baru dengan menitikberatkan pada jenis tari putri, yang pada masa Rd. Sambas Wirakusumah sama sekali tidak mendapat tempat. Keberadaan perempuan pada masa aristokrat feodalisme di lingkungan priyayi sangat dilarang bersentuhan dengan kesenian tari yang saat itu memiliki citra negatif.

Walaupun Rd. Tjetje Somantri menciptakan tarian-tarian berjenis putri, tetapi tetap mempertahankan citra estetika aristokrat sebagaimana lingkungan budaya tempat ia hidup dan dibesarkan. Hal ini bisa dicermati dari taritarian yang diciptakannya, seperti; tari Anjasmara, tari Sulintang, tari Kandagan, tari Ratu Graeni, dan sebagainya. Kalaupun ada yang di luar itu seperti pada tari Merak, tetapi olahan geraknya tetap mengacu pada pandangan estetika aristokrat.

Struktur koreografi yang disusun dalam setiap karya tari Tjetje Somantri, merupakan pengembangan dari ragam gerak pokok yang ada pada genre tari Keurseus. Pada genre tari kreasi baru ini diberlakukan ketetapan dasar pada setiap repertoar tarinya yang berjenis putri, misalnya olahan ruang gerak pada setiap motif dan ragam geraknya tidak boleh mengangkat tangan melebihi bahu karena akan memperlihatkan ketiak; gerak bahu dan pinggul tidak boleh terlalu kuat dan olahan ruang yang lebar, karena dianggap vulgar dan erotis; jarak kedua kaki pada sikap adeg-adeg tidak boleh terlalu lebar, apa lagi mengangkat kaki terlalu tinggi. Itu semua dianggap melanggar kodrat perempuan dan mengurangi keindahannya. Oleh karenanya, tari-tarian karya Rd.Tetje Somantri ini oleh para pemerhati dan akademisi seni tari disebut dengan nama kreasi baru dan ditempatkan sebagai sebuah genre tari tersendiri, yaitu genre tari kreasi baru sebagai genre tari generasi kedua dalam perkembangan seni pertunjukan Sunda.

Lalu bagaiman dengan Jaipongan hasil karya Gugum Gumbira Tirasondjaya pada sekitar awal tahun 1980-an?. Tari ini memiliki cerita dan keunikannya tersendiri yang berbeda dengan para pendahulunya. Karya tari dan penciptanya merupakan dua sisi mata uang yang tidak dapat dipisahkan dari pengamatan, apalagi kiprahnya dalam mengisi perkembangan seni pertunjukan tari Sunda sudah lebih dari 30 tahunan belum ada tanda-tanda akan lahirnya genre tari baru.

Fenomena kelahiran sebuah karya seni yang sangat bercirikan latar budaya penciptanya dan masyarakat penyangganya, telah dijelaskan oleh Adolph S. Thomars dalam teorinya yang tersirat dalam bukunya berjudul Class Systems and The Arts sebagaimana dikutif oleh R.M. Soedarsono (1999: 46) bahwa: 'kehadiran sebuah kelas atau golongan masyarakat akan menghadirkan pula gaya dan bentuk seni yang khas, sesuai dengan selera estetis golongan terentu".

Dengan mengacu pada teori di atas sekaligus memahami substansi penelitian kebudayaan yang menitikberatkan pada persoalan teks dan konteksnya, maka dalam upaya mengeksplanasi keberadaan tari Jaipongan yang fenomenal karena melebihi kurun waktu yang dilampaui para pendahulunya, penulis menetapkan menggunakan 
metode kualitatif dengan pendekatan fenomenologi. Dengan demikian, diharapkan nilai-nilai estetika dan artistik tari lainnya, serta nilainilai budaya yang melatarbelakangi terciptanya Jaipongan dapat diungkap. Untuk hal itu ada dua persoalan pokok yang berpengaruh pada pembentukan citra estetik dan artistik dalam tari Jaipongan, yaitu konsep dan struktur. Kedua sisi tersebut, akan didekati dalam perspektif yang berdimensi etik, estetik, dan akademik. Tulisan ini bertujuan untuk memberikan informasi akademis mengenai genre tari Jaipongan sebagai jenis tari generasi ketiga dalam perkembangan seni pertunjukan Sunda.

\section{Konsep dan Struktur Tari Jaipongan}

Penelitian seni, termasuk tari, substansinya mengungkap dua sisi yang saling melengkapi, yaitu bentuk dan isi. Menurut Jakob Sumardjo (2000: 169) bentuk merupakan representasi dari faktor instrinsik seni yang dibentuk oleh medium atau materialnya. Sejalan dengan itu, Tjetjep Rohendi Rohidi (2011: 53) menyebut faktor intrinsik ini sebagai faktor intraestetik yang dibangun oleh sebuah struktur yang tersistematis, sehingga memiliki pola sususan yang dalam seni tari disebut koreografi. Isi yang merupakan representasi dari nilai gagasan, pikiran, dan perasaan senimannya oleh Sumardjo (2000: 169) disebut sebagai faktor ekstrinsik sedangkan oleh Rohidi (2011: 53) disebut sebagai faktor esktraestetik yang terkandung dalam latar budaya dari kehidupan seniman penciptanya yang sudah merupakan kristalisasi nilai kehidupan sosio-budaya dalam bentuk nilai-nilai, pengetahuan, kepercayaan, dan lingkungan. Dengan demikian, mengungkap keberadaan Jaipongan sebagai sebuah karya tari tidak akan lepas dari konsep penciptaan Gugum Gumbira sebagai penciptanya yang memiliki latar budaya tradisi yang kuat, di sisi lain ia hidup di lingkungan masyarakat kota.

\section{Konsep Penciptaan Gugum Gumbira}

Sejarah perkembangan tari Sunda telah mencatat bahwa etika dalam budaya aristokrat feodalisme kehidupan kaum priyayi/menak Sunda sangat berpengaruh atau mendominasi tata kehidupan masyarakat Sunda. Siapapun yang tidak menggunakannya dalam kehidupan seharihari pasti akan dianggap manusia tidak sopan, tidak tahu diri, tidak tahu adat, dan banyak lagi umpatan sejenis lainnya. Dominasi etika dalam berperilaku tersebut menjadi sebuah tatanan nilai etika adat tradisi yang harus atau wajib dipatuhi, dipelihara dan diwariskan kepada setiap generasi urang Sunda berikutnya. Pada akhirnya, etika tradisi ini menjadi standar ukuran karakteristik masyarakat Sunda, bahkan masih tetap berlaku hingga saat ini walaupun sudah mulai longgar sejalan dengan proses mordenisasi zaman yang terus bergulir.

Tatanan etika aristokrat feodalisme itu, di sisi lain juga sangat berpengaruh terhadap pembentukan kesenian tradisional yang tumbuh dan berkembang di lingkungan kehidupan masyarakat Sunda masa itu. Hal itu terlihat dari kelahiran genre tari Keurseus dan Kreasi Baru yang diciptakan oleh masyarakat aristokrat seperti yang sudah diuraikan di atas.

Pemberlakuan berbagai aturan (patokan) tersebut bagi Gugum Gumbira dipandang sangat membatasi ruang gerak penari, sehingga terasa membelenggu, lamban, dan monoton. Sementara ketika mengamati dan merasakan langsung berbagai bentuk tari produk budaya barat yang tumbuh subur di lingkungan pergaulannya-Kota Bandung (tahun 70-an)-begitu lincah, gesit, enerjik, dan dinamis penuh kebebasan dalam mengolah ruang gerak tubuh penari. Beberapa bentuk kesenian yang sangat digandrungi kaum muda Kota Bandung saat itu, antara lain; Chacha, Salsa, Boll Room, Rock'n Roll, dan sebagainya, menjadi bagian integral dari pergaulan kaum muda Kota Bandung.

Keadaan itulah yang mempengaruhi pemikiran kritis Gugum Gumbira dengan pertanyaan dasar yang terlontar, sebagai berikut: "mengapa kesenian Sunda yang begitu kaya dan beragam tidak tersentuh, apalagi menjadi ajang pergaulan kaum muda Bandung". Bertitiktolak dari pemikiran kritis inilah, Gugum memulai penjelajahannya dalam menemukan apa yang diinginkannya, yaitu bentuk tari tradisional yang bisa menjadi media pergaulan kaum muda kota/modern.

Pemikiran kritisnya yang kuat terhadap keberadaan kesenian tradisional Sunda, jelas bukan hal yang tiba-tiba saja muncul dalam diri seorang Gugum tetapi mengalir dari ayahnya yang pernah menjadi anggota Dewan Perwakilan Rakyat Daerah (DPRD) Kotamadya Bandung. Menurut 
Gugum, semasa ayahnya menjadi anggota DPRD tersebut, ia salah seorang yang paling kritis dan vokal dalam menyuarakan aspirasi masyarakatnya, sehingga banyak dikenal dan disegani oleh kawankawannya di DPRD tersebut (Edi Mulyana dan Lalan Ramlan, 2012: 15). Kebiasaan yang kritis dan vokal ayahnya itu tertanam dalam kehidupan Gugum yang selalu kritis dalam menyikapi situasi sosial dan vokal dalam menyuarakan keinginan untuk mengangkat serta menghidupkan kembali keberadaan kesenian yang termarginalkan, karena dianggap seronok, vulgar, dan kurang bernilai.

Gugum memiliki perhatian yang besar terhadap perkembangan kehidupan kesenian tradisional Sunda. Ia ditempa sejak kecil dengan pengalaman dan pengetahuan seni dan budaya Sunda oleh ayahnya melalui latihan Pencak Silat (maenpolPenca: Sunda). Setelah jurus-jurus dasar tersebut dikuasai dengan baik, selanjutnya diajarkan Penca kembang yang sederhana seperti tepak tilu. Adapun pemikirannya yang moderat, karena pendidikannya yang cukup tinggi yaitu sarjana dan pergaulannya yang luas dengan berbagai strata sosial yang berbeda.

Dalam meniti karir berkeseniannya, Gugum memulainya dengan belajar berbagai jurus Penca dari berbagai aliran, seperti; Cikalong, Cimande, dan Sabandar. Ia belajar aliran Cikalong dan Cimande dari Bah Saleh, Ki Bacih, dan Ki Sanhudi. Proses pembelajaran yang diterimanya tidak saja sebatas fisik, tetapi sampai pada unsurunsur di luar fisik, yang dalam dunia persilatan sering disebut kebatinan. Selain ayahnya sendiri, Ki Bacih dan Ki Sanhudi inilah yang banyak mewarnai prinsip berkeseniannya. Pendalamannya terhadap Pencalmaenpo, menggiring Gugum pada penemuan bagian padungdung kendor yang menjadi landasan inspiratif munculnya kebebasan atau fleksibilitas irama dalam Jaipongan, sehingga membuka ruang atau peluang bagi penari untuk bebas bergerak menampilkan jurus-jurus dengan irama tidak terikat.

Petualangannya dalam proses berkesenian terjadi terutama pada masa setelah berkeluarga, Ia melangsungkan pernikahan pada tanggal 18 April 1968 dengan perempuan yang dicintainya bernama Euis Komariah yang pada saat itu sudah menjadi penembang Cianjuran yang handal. Dari pernikahannya tersebut, Ia dikaruniai empat orang anak, yaitu: Mira Tejaningrum (Bandung 4 Maret
1969), Ine Dinar (Bandung 24 Pebruari 1970), Asye Ratna Mantili (Bandung 4 Agustus 1973), dan Sonda Utami Dewi (Bandung 26 Pebruari 1978).

Gugum mempelajari berbagai jenis kesenian seperti Ketuk Tilu dari Ki Sanhudi, Bu Jubaedah, dan Bah Akil. Secara koreografis, tarian pada kesenian Ketuk Tilu masih menggunakan struktur koreografi yang terdiri dari ragam gerak bukaan, pencugan, nibakeun, dan beberapa gerak mincid. Keberadaannya seperti itu memberikan inspirasi terhadapnya dalam persoalan struktur tarian. Oleh karena itu kesenian tradisional Ketuk Tilu pada gilirannya menjadi dasar struktur koreografi penciptaan tari Jaipongan.

Setelah belajar Ketuk Tilu, Gugum berguru kesenian Topeng Banjet pada Bah Epeng, Ali Saban, dan Bah Pendul. Dalam penampilan penari perempuan umumnya menggunakan ragam hias yang cukup menarik mulai dari bagian rambut menggunakan hiasan kembang, busananya menggunakan kebaya yang dihiasi dengan toka-toka atau tola, kewer, dan bagian bawahnya menggunakan sinjang. Kesenian ini umumnya diiringi oleh seperangkat waditra Ketuk Tilu, namun ada pula yang menggunakan gamelan lengkap berlaras salendro. Gerak tarinya cenderung erotis (terkenal dengan istilah eplok cendol atau goyang Karawang yang disajikan oleh kembang topeng atau penari primadona). Hal ini memberikan penebalan terhadap munculnya nuansa erotis dalam Jaipongan. Gugum (2008) menegaskan bahwa dalam mempelajari gerakgerak Penca, Ketuk Tilu, dan Topeng Banjet dilakukan sampai hatam".

Pada proses hataman itulah Gugum menjalani sebuah prosesi akhir yang disebut upacara tawajuh. Ia dimandikan dengan air kembang yang diwadahi dengan goong keramat. Menurut Askin, seniman Karawang, tidak semua murid Bah Pendul ditawajuh, hanya murid-murid yang dianggap istimewa saja yang diperlakukan demikian. Harapannya adalah agar orang yang dimandikan air kembang dari goong tersebut kelak namanya akan bergema seperti suara goong.

Setelah berguru kepada beberapa tokoh Topeng Banjet, giliran berikutnya yang dipelajarinya adalah seni Kliningan Bajidoran. Daerah Pantai Utara Jawa Barat, khususnya Karawang dan Subang, memiliki banyak grup kesenian Kliningan 
Bajidoran yang dalam pertunjukannya selalu melibatkan kelompok bajidor (menunjuk kepada para pelaku yang berperan secara aktif dalam peristiwa Bajidoran), yakni meminta lagu, menari, dan memberi uang jaban (saweran; memberikan uang kepada sinden atau pangrawit).

Ketertarikan Gugum pada kesenian ini karena terdapatnya kesamaan bentuk sajian dengan beberapa jenis kesenian yang telah dipelajari sebelumnya yaitu Ketuk Tilu, Penca, dan Topeng Banjet. Tarian ini kaya akan variasi gerak yang ditarikan secara spontan, improvisasi, dan unik, baik yang ditarikan oleh para pesinden maupun para bajidor. Untuk mengetahui lebih dekat kesenian tersebut ia memutuskan ikut ngabajidor. Gugum mulai berkenalan dengan beberapa tokoh bajidor dari Karawang seperti Atut, Askin, dan Dimyati, serta Lurah Hilman, Upas Omo, dan Lurah Joni dari Subang. Secara khusus dalam peristiwa Bajidoran tersebut ia selalu memberikan beberapa krat (kotak) minuman bir untuk para bajidor dan mengeluarkan banyak uang untuk jaban.

Sejak itulah Gugum menemukan beberapa seniman potensial yang memiliki keahlian khusus, seperti Suwanda dan Dali sebagai penabuh kendang, Idjah Hadidjah, Umay Mutiara dengan suara emasnya sebagai sinden, serta Atut, Askin, dan Upas Omo dengan ibing khas Bajidoran-nya. Mereka itulah yang pada gilirannya diikut-sertakan dalam proses berkesenian selanjutnya. Selain itu, Ia juga menemukan pola-pola tepak kendang serta berbagai ragam gerak, seperti bukaan, pencugan, nibakeun, dan motif-motif tepak dan gerak mincid. Lebih lanjut pola-pola tersebut menjadi kerangka dasar Jaipongan yang selanjutnya menjadi kerangka garap Jaipongan. Euis Komariah, istri Gugum Gumbira, menegaskan bahwa Jaipongan yang dikenal dewasa ini merupakan hasil jerih payahnya, bukan saja secara moral tetapi material pun ia korbankan untuk menciptakan Jaipongan.

Sebagai seorang seniman, Gugum mempunyai prinsip bahwa dalam berkarya itu pertama adalah keberanian, dalam arti keberanian kreatif. Selain itu tidak boleh takut disalahkan atau dikritisi oleh orang lain. Hal yang diutamakan adalah mampu membuat lepas dari permasalahan apakah karya itu berkualitas atau tidak. Menurutnya, tanpa keberanian seseorang tidak akan mampu menghasilkan sesuatu. Seorang seniman yang tidak mempunyai keberanian walaupun berpotensi akan menjadi mandul. Ia menambahkan bahwa keberanian tersebut diimbangi pula oleh pengetahuan dan pengalaman serta berpegang teguh pada prinsip-prinsip kekaryaan seperti adanya kesatuan, harmoni, transisi serta berpegang teguh pada norma-norma masyarakat seperti adat, cara, dan kebiasaan-kebiasaan. Prinsip selanjutnya menurut Gugum Gumbira adalah "terbuka terhadap segala saran dan kritik dari orang lain, tidak boleh alergi terhadap saran dan kritikan yang disampaikan orang lain. Hal ini dibuktikan ketika ia mendatangkan para seniman seperti Nandang Barmaya, Samin, Tosin, Tati Saleh, Omik Hidayat, Suwanda, dan Dali untuk diajak bekerjasama dan berdiskusi untuk menghasilkan karya-karya yang diinginkannya. Karya-karyanya diciptakan se-orisinal mungkin, tidak menjiplak atau meniru hasil orang lain.

Gugum Gumbira memiliki pandangan yang sederhana tentang dunia tari atau menari, Ia mengatakan: "ngigel mah moal jauh ti leungeun jeung dua suku, paeh hiji-hirup hiji" (menari itu hanya menggerakkan dua tangan dan dua kaki, satu statis karena menjadi tumpuan berat tubuh dan yang satu lainnya dalam posisi bebas). Kalimat ini sangat menekankan pada ketidakstabilan posisi tubuh, dalam arti posisi tubuh harus selalu dalam keadaan 'hidup' (plastis; tidak statis). Untuk kepentingan itu, terutama bagian kaki harus dalam keadaan asimetris. Maksud dari asimetris atau "paeh hiji hirup hiji" adalah difokuskan pada posisi kaki dalam keadaan pasang/kuda-kuda atau adeg-adeg. Kaki yang satu bersifat menahan atau menjadi tumpuan berat tubuh ( $p a e h)$ dan yang lainnya bersifat hidup atau siap bergerak bebas dengan berbagai kemungkinan; motif gerak, arah gerak, dan/atau tempo dengan intensitas gerak yang berbeda.

Ada dua faktor yang membentuk daya dinamika irama dalam tarian Jaipongan, yaitu di satu sisi karena Gugum sangat mengidolakan gaya menari dari seorang ronggeng yang pada masa aristokrat dipandang rendah, tetapi bagi Gugum justru sebaliknya. Ia menangkap daya pesona menari yang luar biasa. Oleh sebab itu, pada bagian pencugan (isi) dalam koreografi Jaipongan adalah merupakan kunci-kunci jurus untuk menghindar, menyerang, menangkis, mendorong, bahkan menantang pasangannya (para penari 
pria). Daya pesona ronggeng itu diungkapkan oleh Atang Warsita, seorang seniman karawitan Sunda dalam beberapa bait syairnya berikut.

kewes pantes
singset dangdosanana
adu manis jeung gerak ibingna
rindat soca nyarengan
sumanding imut pangirut
matak bengong anu melong
gereget keur nu neuteup
sok matak ngahudang kasmaran para jajaka
lali kana temah wadi
kurengkakna nyi ronggeng lamun keur mi-
dang
sok asa ngarasa enya dilayanan
geuning padahal ukur pulasan

Syair lagu di atas merupakan gambaran seorang ronggeng yang cantik, menarik, berpakaian ketat, serasi dengan gerak tarinya. Lirikan mata dan senyumnya yang menawan, membuat siapa pun yang melihat akan terpana, bahkan jatuh cinta. Para lelaki akan menjadi lupa diri, seolah-olah mendapat belaian.

Di sisi lain, penekanan pada kekuatan nilai estetika tari yang dinamis dengan intensitas pergerakan yang tinggi sangat mencerminkan karakteristik kaum perempuan Sunda (mojang Priangan) yang cantik, menarik, ramah, anggun, gemulai, gesit, lincah, dan memiliki daya tarik yang menawan. Gambaran pesona mojang Priangan itu juga diungkapkan oleh Hj. Iyar Wiyarsih, seorang pesinden handal dalam lagu ciptaannya "Mojang Priangan" berikut.

\section{angkat ngagandeuang \\ bangun taya karingrang \\ nganggo sinjang dilamban \\ Mojang Priangan}

$$
\begin{aligned}
& \text { umat-imut lucu } \\
& \text { sura-seuri nyari } \\
& \text { larak-lirik keupat } \\
& \text { Mojang Priangan } \\
& \text { Reff: diraksukan kabaya } \\
& \text { nambihan cahayana } \\
& \text { dangdosan seudeurhana } \\
& \text { Mojang Priangan }
\end{aligned}
$$

Lirik lagu di atas menggambarkan sosok perempuan Sunda yang bersahaja dengan busana kain dan kebayanya, senum dan lirikan matanya, dengan langkahnya yang tenang berwibawa, menambah aura daya tariknya.

Mencermati konsep di atas, Gugum Gumbira menghendaki gambaran ideal perempuan Sunda itu secara realistis yang terekspresikan dalam tariannya, tidak seperti yang dilakukan oleh Rd. Tjetje Somantri yang mengangkat daya pesona perempuan Sunda melalui analog dalam dunia imajinasi, misalnya pada tari Anjasmara, Sulintang, Kandagan, dan Ratu Graeni. Ronggeng adalah figur perempuan Sunda yang nyata; kegesitan, kelincahan, daya erotis, yang disajikan dalam beberapa bentuk kesenian tradisional kerakyatan, seperti pada Ketuk Tilu, Tayuban, Topeng Banjet, Bajidoran, dan sebagainya. Begitu pula dengan kecantikan, kegemulaian, keramahan, keanggunan, kegesitan, kelincahan, dan kekuatan mojang Priangan. Idealisasi figur perempuan Sunda ini dilukiskan dalam beberapa ungkapan, seperti berikut. Berkaitan dengan kesempurnaan tubuh: ditilik ti gigir lenggik; diteuteup ti hareup sieup; disawang ti tukang lenjang; kulitna koneng umyang. Berkaitan dengan kecantikan wajah: tarangna jamentrang herang; halisna ngajeler paeh; socana seukeut moncorong; pipina ngadaun seureuh; gadona endog sapotong; pangambung kuwungkuwungan; lambeyna kucup kastuba. Berkaitan dengan cara berjalan: angkatna lir macan teunangan.

Bila ditarik lebih dalam, perempuan Sunda pada kisah-kisah mitologi pantun, wawacan, dan sejarah ketokohan perempuan Sunda, seperti Sunan Ambu, Dayang Sumbi, Dewi Asri, Dewi Sri, Kawung Anten, Nyi Mas Gandasari, dan banyak lagi yang lainnya merupakan figur-figur perempuan Sunda yang diposisikan pada derajat yang tinggi. Gugum sangat terpesona oleh sosok perempuan Sunda, maka eksploitasi karakteristik perempuan Sunda sangat tercermin dalam karya tari Jaipongan yang diciptakannya.

Beranjak dari itu, Gugum berupaya menggali lebih dalam tentang potensi seni, termasuk ruh kasundaan-nya. Berkaitan dengan itu, dalam proses kerja kreatif ia melakukan penghayatan terhadap tatanan kearifan tradisi, bergaul secara erat, berdialog, dan saling memberi dengan para seniman di lingkungan kehidupannya yang menjadi pelaku dan pemilik kebudayaan. Penting untuk dipahami, karena ada penegasan bahwa 
nilai-nilai lama dalam suatu masyarakat sebenarnya terus hidup di tengah-tengah perubahan nilainilai lainnya. Sebagaimana keberadaan figur perempuan dalam pandangan semesta masyarakat Sunda lama yang menduduki posisi bermartabat dan dimuliakan.

Semua itu disempurnakan oleh aura sensualitas keperempuanan yang menjadi sarinya (mamanis/pasieup; Sunda) yang orang kebanyakan menyebutnya dengan istilah $3 \mathrm{G}$ (gitek, géol, dan goyang). Tiga $G$ dalam konteks ini sangat ditentukan oleh faktor kepribadian dari seorang penari, karena yang akan terlihat dengan kasat mata adalah apakah muncul dari sebuah kewajaran berdasarkan faktor penguasaan teknik menari atau muncul dari upaya eksploitasi yang bersifat verbal dan seronok.

Penting dipahami mengenai hal ini, karena ada persoalan nilai yang berlaku dalam tatanan budaya Sunda bahwa gerakan gitek, geol, dan goyang bukan semata-mata untuk mengumbar erotisme, sensualitas, dan seksualitas, tetapi terkait dengan makna "kesuburan". Mengenai hal ini Sumardjo (2003: 99) menjelaskan, bahwa pergerakan dari pusar adalah simbol kecerdasan, sedangkan pinggul atau genital merupakan simbol kreativitas.

\section{Struktur Tari Jaipongan}

Struktur garap yang disusun oleh Gugum diawali dengan bubuka, yakni awal tarian atau introduksi tarian berdasar pada pola tepak kendang dan gending atau sebaliknya pola gerak yang diisi oleh tepak kendang dan gending (berdasarkan lagu dan gending atau sebaliknya). Kedua, bagian tengah diisi dengan pencugan yaitu berupa jurus-jurus dari ibingan Penca (Penca kembang). Bagian tengah ini merupakan inti atau gerak pokok Jaipongan, dan sebagai sisipan atau gerak peralihannya digunakan gerak mincid. Ketiga adalah penutup, yakni dari pola-pola gerak sorong atau nyéréd, yang berpijak pada pola gerak Ketuk Tilu pada bagian akhir (arang-arang dan nyorong atau nyéréd) atau nibakeun. Pola-pola tersebut menjadi pijakan atau acuan dalam setiap tarian yang diciptakannya. Namun demikian polapola tersebut begitu lentur/atau elastis, sehingga memberikan peluang bagi kreator lainnya untuk mengembangkan motif-motif dari pola tersebut.

Pada rentang waktu yang sudah lebih dari 30 tahun, Gugum Gumbira tercatat telah menciptakan repertoar tari sebanyak 13 buah yaitu Rendeng Bojong, Keser Bojong, Setra Sari, Sonteng, Toka-Toka, Senggot, Bulan Sapasi, Iring-



Gambar 1. Bagan alur penciptaan dan perkembangan Jaipongan 
Iring Daun Puring, Pencug Bojong, Ringkang Gumiwang, Rawayan, Kawung Anten, dan Tawadu. Keseluruhan karya repertoar tari tersebut menunjukkan konsistensi penggunaan struktur koreografi yang sama, tetapi dalam bentuk penyajian yang bervariasi bersesuaian dengan lagu dalam karawitan tari yang mengiringinya, begitu pula dengan ditunjang oleh pengembangan penataan desain busana yang berbeda pada setiap repertoar tarinya (Gambar 1).

Apabila menelusuri perjalanan pembentukan genre tari Jaipongan diketahui bahwa: Pertama, repertoar tari pertama yang diciptakan oleh Gugum Gumbira merupakan tari pasangan (pa/ pi) yang dinamai Ketuk Tilu Perkembangan. Penggunaan nama tersebut mengundang reaksi keras dari para seniman tari tradisional masa itu. Walaupun pada akhirnya pihak yang tidak setuju itu mengusulkan untuk menggantinya dengan nama lain yang lebih sesuai. Argumentasi dari pihak yang tidak setuju mengatakan bahwa nama Ketuk Tilu biarkanlah melekat sebagai nama yang sudah mengidentitas dari sebuah bentuk kesenian yang sudah ada dan masih hidup sebagai warisan tradisi masyarakat Sunda, yaitu kesenian tradisional Ketuk Tilu. Kedua, Ketuk Tilu merupakan salah satu dari empat sumber pembentukan struktur tari Jaipongan, dan tiga sumber lainnya adalah PencalMaenpo (Pencak silat), Topeng Banjet, dan Bajidoran. Oleh karena itu, mereka menyarankan agar karya Gugum Gumbira ini memiliki namanya sendiri yang baru dan khas.

Kesenian Ketuk Tilu tersebut merupakan jenis kesenian pergaulan/hiburan di kalangan rakyat, sehingga memiliki bentuk penyajian dengan pola berpasangan, yaitu antara penari profesional perempuan (ronggeng) dengan penari partisipan (laki-laki/pria) dari kalangan penonton yang hadir pada acara tersebut. Profesi ronggeng telah banyak ditulis oleh para ahli sebagaimana disampaikan Endang Caturwati (2006: 2-3) berikut.

Ronggeng merupakan fenomena budaya yang banyak disinggung dalam berbagai tulisan, antara lain; Kidung Sunda (Karya sastra Jawa Tengahan, 1500-an); Serat Centhini (1814), Ronggeng Dukuh Paruk (Novel, Ahmad Tohari, 2004), The History of Java (Thomas Stamford Raffles, 1817),
Art in Indonesia: Continuities and Change (Claire Holt, 1967), Old Javanese English Dictionary (P.J. Zoetmulder, 1982), Children of The Colonial State: Population Growth and Economic Develepment In Java 1795-1880, 1989), Erotic Triangles: Sundanese Men's Improvisational Dance in West Java Indonesia (Henry James, 2001). Tulisan-tulisan tersebut pada umumnya memaparkan ronggeng sebagai perempuan penari kalangenan. Budaya ronggeng dikelilingi banyak pria, dipuja, disanjung, atau juga dijadikan patner tidak saja di arena pertunjukan, tetapi juga di atas ranjang.

Penulis menemukan sebuah manuskrip tentang peristiwa pendirian Sekolah Ronggeng di lingkungan Kraton Cirebon yang ditulis oleh J.A. van Middelkoop dengan judul "Reglement Van de Tandak of Ronggeng Inholen te Cheribon (1809)". Manuskrip ini memuat sejumlah 22 pasal yang dituangkan dalam 15 halaman, isinya meliputi; pemberian ijin pendirian tiga sekolah ronggeng di tiga Kraton Cirebon, penetapan lokasi, penetapan kurikulum pembelajaran, penetapan persyaratan bagi siswa/murid, penetapan jadwal pertunjukan, dan penetapan larangan membawa pergi ronggeng (Lalan Ramlan, 2008: 70-76). Terutama yang paling menarik adalah pada Art 18 yang berbunyi:

"Des morgens ten zeeven uuren zal het oderwijs der kelass moedeen en leebees in het leezeen schrij ven en den Koran etc een aan aanvangneemen en eerst, des middagsten elf uuren mogen eindigen terwijl des na de middag van tween tot sessen, en in het zingen en rongeng speel len gegeven zal moeten warden en zulks dagelijks except op feest of andere het lingen dagen".

Pasal ini berisi antara lain penetapan kurikulum seperti; pagi hari pelajaran menulis dan membaca Qur'an dan adat istiadat Cirebon, sore hari nyanyi dan Tari Ronggeng". Berdasarkan keterangan di atas ada beberapa catatan penting yang perlu dicermati, antara lain isi kurikulum pada sekolah ronggeng jelas mencerminkan citra profesi ronggeng yang bermartabat, karena dibekali dengan pendidikan, keagamaan (Islam), keahlian menyanyi dan menari, serta wawasan budaya adatistiadat Cirebon. Hal ini sangat berbeda dengan yang dilukiskan oleh para penulis sebelumnya 
yang menggambarkan keadaan ronggeng pasca tahun 1809. Disebutkan oleh Raffles (1965: 381), bahwa ... Their conduct is generally so incorrect, as to render the title of ronggeng and prostitute synonymous ...

Dengan demikian, persoalan dunia ronggeng yang selama ini lebih banyak diekspose citra negatifnya perlu dikaji ulang. Hal ini penting segera dilakukan, agar pemahaman masyarakat terhadap profesi Ronggeng menjadi utuh. Citra positif ronggeng yang selama ini belum tergali oleh para pengamat atau peneliti tari ternyata telah ditangkap sejak lama oleh Gugum Gumbira. Potensi daya pukau/pesona ronggeng ia temukan dalam Ketuk Tilu, Topeng Banjet, dan Bajidoran, sedangkan dari PencalMaenpo (Pencak Silat) ia temukan jurus-jurus kunci yang melengkapi gambaran kegesitan seorang ronggeng ketika menari dalam menghindar, menekan, mendorong, dan membuka peluang para lelaki untuk masuk, tetapi akan dikunci apabila melakukan gerakangerakan yang membahayakan dirinya. Dalam hal ini Gugum melihat seorang ronggeng bagai seorang pesilat (jawara) perempuan. Terkait dengan hal itu Sumardjo (2006: 92) menjelaskan, bahwa:

Seni adalah cahaya atas realitas. Realitas yang selama ini kita nilai biasa dan rutin, tiba-tiba diberi cahaya baru sehingga nampak sesuatu yang tak kita lihat selama ini. Realitas nampak baru, nampak jelas, nampak punya kedalaman, nampak lebih benar. Seni pada awalnya pertemuan sebuah kebenaran atas realitas. Kebenaran itu selama itu tersembunyi di balik realitas. Setiap orang barangkali dapat mengalami peristiwa semacam itu, tetapi tetap tersimpan bagi dirinya. Seorang seniman, ilmuan, filsuf, agamawan, dapat mewujudkan dalam simbol-simbol. Untuk itu diperlukan keterampilan teknik dan kecerdasan cara mewujudkannya. Dan kalau orang itu cukup terampil, terlatih dan cerdas, maka ia akan bisa cepat mewujudkannya dalam bentuk benda.

Pola penyajian berpasangan terutama dalam Ketuk Tilu itulah, yang masih kental diadopsi ke dalam tari Ketuk Tilu Perkembangan, nama yang dipakai saat itu.

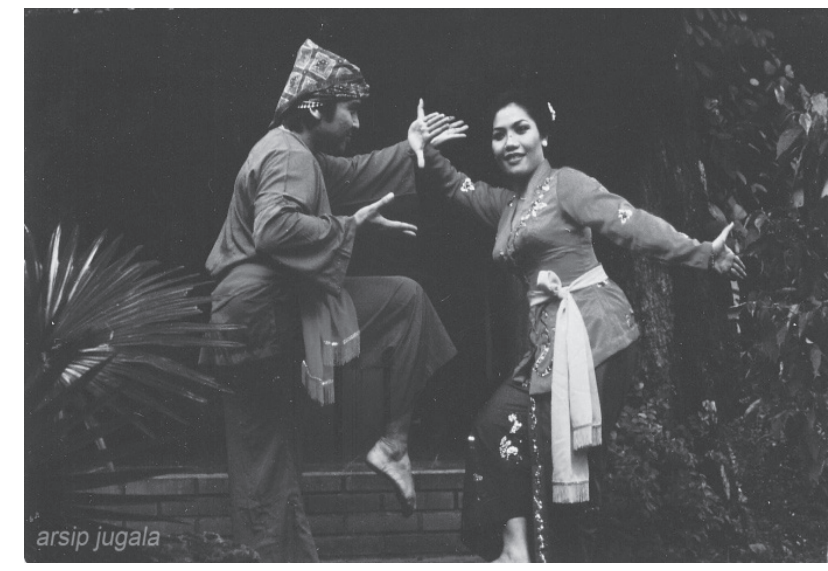

Gambar 2. Gugum Gumbira dan Tati Saleh dalam repertoar tari Rendeng Bojong (Foto: Koleksi Jugala, 1980).

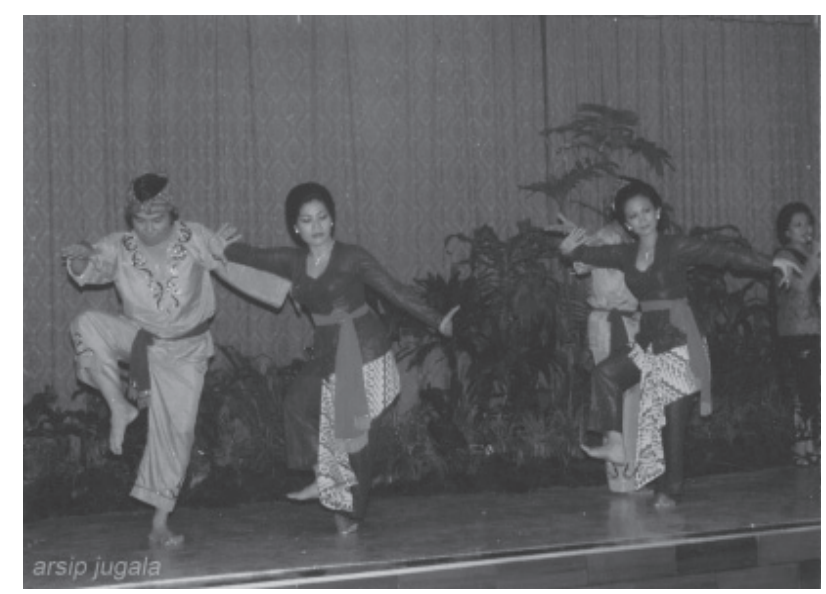

Gambar 3. Gugum Gumbira dkk., dalam Ketuk Tilu Perkembangan (Foto: Koleksi Jugala, 1978).

Ketegangan akibat pro dan kontra dari masyarakat Sunda, terutama para seniman konservatif dalam menyikapi kehadiran tari olahannya itu pada akhirnya disikapi dengan arif dan bijak oleh Gugum Gumbira. Ia bahkan memosisikan sebagai sebuah tantangan untuk segera menemukan nama yang lebih tepat. Selang beberapa tahun beredarlah sebuah nama yang langsung populer di tengah-tengah kehidupan masyarakat Sunda yaitu Jaipong. Repertoar tari pertama yang diluncurkan diberi nama Rendeng Bojong dina lagu Banda Urang. Nama tarian ini dalam waktu singkat dikenal di seluruh Jawa Barat, bahkan melampaui popularitas dua genre tari yang sudah ada sebelumnya, yaitu; genre tari Keurseus dan genre tari Kreasi Baru (Gambar 3) 


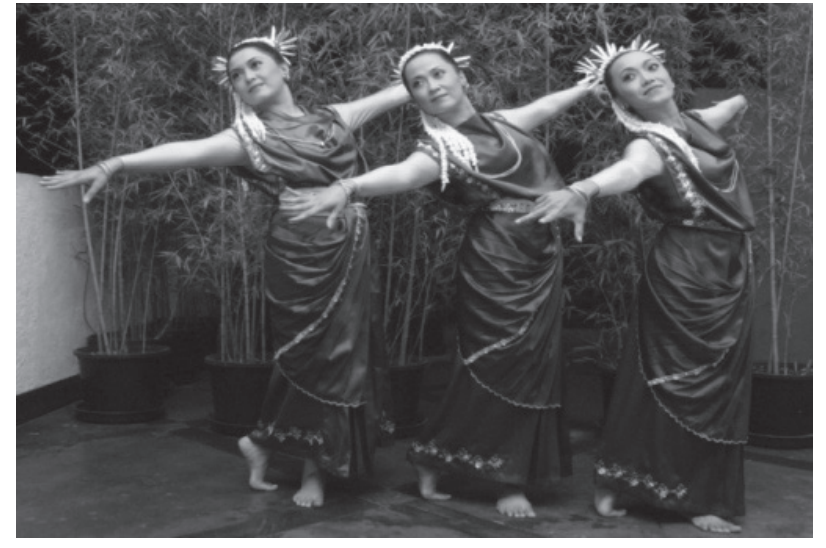

Gambar 4. Penari Jugala dalam Repertoar tari Rawayan repertoar (Foto: Koleksi Jugala, 2006)

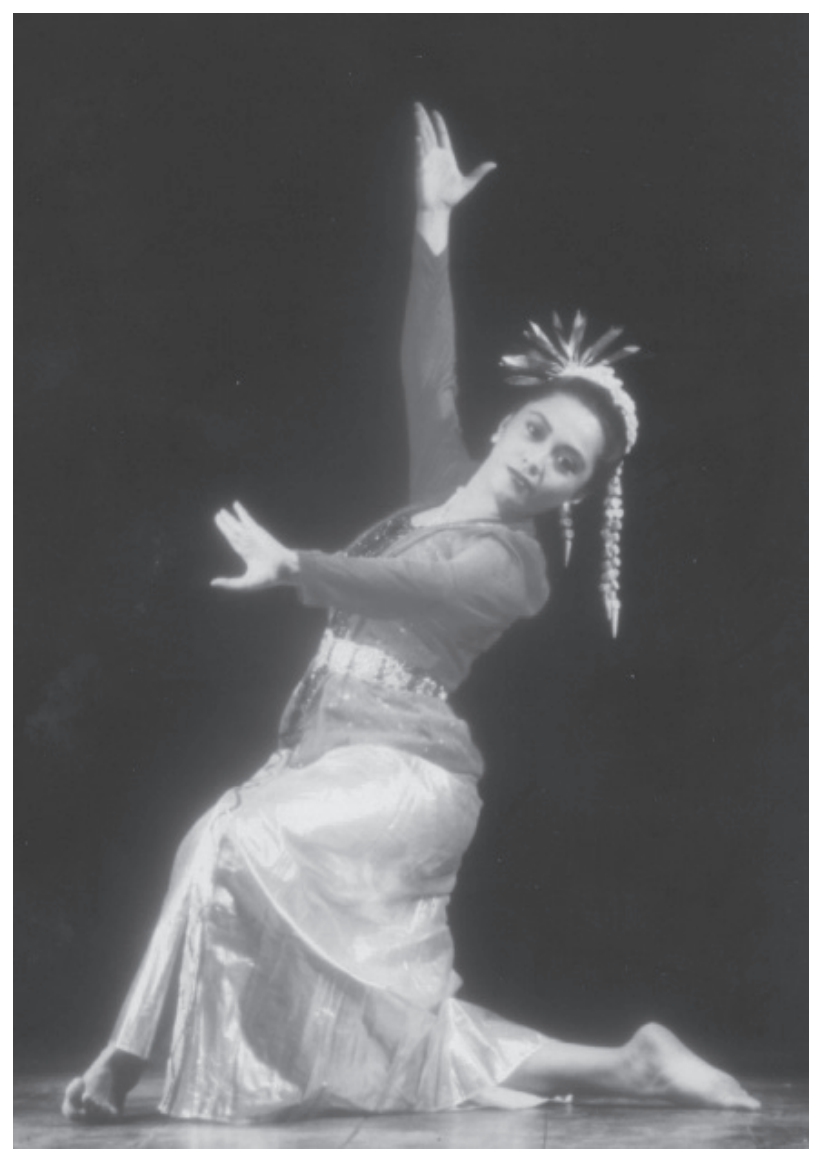

Gambar 5. Mira Tejaningrum dalam repertoar Tari Kawung Anten (Foto: Koleksi Jugala, 2006)

Beberapa karya selanjutnya yang diciptakan Gugum ada yang masih mempertahankan jenis penyajian tari berpasangan, seperti; Toka-Toka dan Ringkang Gumiwang. Akan tetapi mayoritas repertoar tari yang diciptakannya berjenis tari tunggal, baik putra yang hanya ada satu yaitu Penjug Bojong, maupun putri seperti; Keser Bojong, Setra Sari, Iring-Iring Daun Puring, Sonteng, Senggot, Rawayan, dan Tawadu. Satusatu karya yang bertema, yaitu Kawung Anten.
Perkembangan penciptaan tari Jaipongan ini, tidak saja menunjukkan perubahan pada koreografinya saja tetapi juga pada desain busana.

\section{Struktur Koreografi Tari}

Struktur Koreografi tari dibangun oleh empat fase ragam gerak, yaitu; bukaan, pencugan, nibakeun, dan mincid. Bukaan yaitu fase ragam gerak awal, biasanya dimulai setelah goong dan diadopsi dari ragam gerak awal dalam tarian Ketuk Tilu dan Bajidoran. Fase bukaan ini di dalamnya terdiri dari gerak-gerak, seperti misalnya; kuda-kuda pasang, luncat, depok, dan sebagainya. Kemudian pencugan yaitu fase ragam gerak yang lebih merupakan permainan jurus yang sudah distilasi untuk kebutuhan tari (gerak ini bisa dilakukan di tempat maupun berpindah tempat), lazimnya disebut gerak pokok atau ibing pola, misalnya, besot, siku, bandul, tajong, jérété, peupeuh, dan sebagainya. Nibakeun yaitu ragam gerak yang merupakan rangkaian gerak akhir atau sering disebut ngagoongkeun (gerak penutup), misalnya galieur, godeg, jeblag, jedag, dan sebagainya. Untuk menggabungkan berbagai fase ragam gerak tersebut dipakai fase ragam gerak mincid, seperti: kuntul longok, girimis, adu manis, ban karét, kulawit, bongbang, dan sebagainya. Semua ragam gerak itu menjadi kerangka dasar dalam konstruksi bangunan Jaipongan, sehingga secara struktural memiliki awalan, tengah, dan penutup. Ketiganya dipertautkan dengan gerak penghubung.

Bentuk garapan Jaipongan pada umumnya disajikan secara tunggal dan berpasangan, serta memiliki warna mandiri yang khas baik dari sisi koreografi, iringan, dan rias busananya. Jaipongan yang diciptakan oleh Gugum Gumbira dikembangkan dan disebarluaskan melalui Padepokan Seni Jugala, serta Jugala Record. Secara konseptual Gugum telah mampu berbuat sesuatu untuk kepentingan orang banyak. Kesemuanya itu digali dari fenomena-fenomena yang tengah terjadi. Kemunculan karya Jaipongan ini adalah sebuah jawaban atas kefakuman kreatifitas yang terjadi pada dekade tahun 70-an di Jawa Barat. Hal ini Ia jadikan peluang untuk mengisi dan menawarkan suatu karya baru yang berorientasi pada seni tradisi yang pernah digemari oleh rakyat Jawa Barat. 
Fleksibilitas struktur tari Jaipongan bisa dilihat setiap repertoar tarinya, misalnya: Rendeng Bojong, Toka-Toka, Iring-Iring daun Puring, Senggot, dan Ringkang Gumiwang dimulai dengan mincid; Keser Bojong dimulai dengan bukaan; Sonteng, Setra Sari, dan Pencug Bojong dimulai dengan pencugan, sedangkan nibakeun, karena posisinya sebagai ragam gerak penutup menuju goong, posisinya pada setiap repertoar tari akan ditentukan oleh posisi goongan.

\section{Karawitan Tari}

Proses pembuatan atau penyusunan gending tari berjalan agak rumit dan memakan waktu yang lama, karena adanya perbedaan visi dan persepsi yang mendasar antara Gugum Gumbira dengan para penata gending yaitu Nandang Barmaya yang dibantu oleh Tosin dan Samin. Pada awalnya mereka tidak mengerti keinginan Gugum, hal ini didasari oleh beberapa kaidah gending yang mereka anggap sudah baku dan tidak mungkin untuk diubah. Pola irama yang dipaksakan untuk mengikuti ritme gerak dipandang akan merusak pakem-pakem tradisi, sehingga terjadi tarik menarik antara konsepsi Gugum dengan penata gendingnya. Pada satu pihak Gugum menghendaki bahwa gending sebagai pengiring mampu mengiringi konsep geraknya, di sisi lain ia menekankan bahwa sudah saatnya berani ke luar dari pakem-pakem yang sudah ada. Pada awalnya nampak terjadi kebuntuan dalam penuangan idenya tersebut karena para penata karawitan belum mampu menterjemahkan apa yang dikehendakinya. Akhirnya gending belum mewadahi konsep garapnya. Walaupun terbentuk, masih terlihat unsur pemaksaan. Gugum memberikan nama dengan sebutan Ketuk Tilu Perkembangan. Dikatakan demikian, karena secara koreografi telah terjadi pembaharuan, sementara gending untuk mengiringi tariannya belum beranjak dari bentuk tradisi.

Rupanya Gugum perlu mencari alternatif lain dalam pembaharuan gendingnya ini. Dia mencari seniman lain sebagai pendukung tambahan. Ketika sedang melihat suatu pertunjukan Kiliningan, dia melihat seorang penabuh kendang yang dari sisi usia masih muda dan memiliki potensi dalam keterampilan memainkan kendang, yaitu Suwanda dari Karawang. Suwanda dipertemukan kepada para penata gending seperti: Nandang
Barmaya, Samin, dan Tosin, lalu disuruh menampilkan kebolehannya dalam menabuh kendang yang diiringi dengan gamelan oleh ketiga orang tersebut. Rupanya apa yang dilakukan oleh Suwanda sangat terbiasa dalam pertunjukan Kiliningan, Tanjidor dan Topeng Banjet yang kaya akan motif tepak kendang dalam irama tradisi, namun ternyata tetap tidak merubah struktur lagu atau gending.

Melihat hal demikian terbukalah pandangan Nandang Barmaya, Tosin, dan Samin untuk mulai memahami keinginan Gugum. Dalam pikiran mereka sudah saatnya mengadakan pembaharuan, sebab pada hakekatnya apa yang dilakukan bukan suatu perusakan tetapi merupakan pengembangan. Akhirnya timbul gagasan baru dari keempat orang tersebut, Suwanda dan Tosin berupaya untuk menghadirkan motif-motif baru pada tepak kendang, sementara Nandang Barmaya dan Samin berupaya untuk mengembangkan dan menciptakan gending-gending yang baru pula, yang selanjutnya diselaraskan dengan konsep tarinya. Sejak saat itulah terjadi jalinan komunikasi yang konvergen antara Gugum dengan para penggarap gendingnya.

Ternyata para penggarap gending yang dipercaya Gugum Gumbira tersebut merupakan seniman-seniman yang handal. Ini tampak pada garap awal gending Jaipongan tersebut yang mencuatkan warna baru dalam kancah kreativitas karawitan Sunda. Pola gendingnya terdiri atas intro, bagian tengah, dan gending penutup. Bagian intro merupakan terobosan baru sebagai pengganti karawitan arang-arang dalam Ketuk Tilu. Bagian ini memberikan peluang bagi Gugum untuk menampilkan teknik muncul atau gebrakan awal dalam tariannya. Pada sisi lain ini memberikan peluang bagi penabuh kendang untuk menampilkan kebolehannya. Gugum pun begitu kompromis dengan para penata gendingnya termasuk mendiskusikan judul lagu. Pada saat itu lagu yang ditetapkan adalah Daun Pulus Keser Bojong, tetapi tariannya diberi nama Keser Bojong. Ini merupakan momentum yang paling penting dalam penciptaan Jaipongan setelah melalui proses panjang, yang sebelumnya belum menemukan bentuk yang diinginkan hingga terpaksa diberi nama Ketuk Tilu Perkembangan. Dengan kata lain, Keser Bojong merupakan bentuk paling awal dari genre tari Jaipongan. 
Perkembangan selanjutnya justru menempatkan kekuatan karya Gugum Gumbira dalam Jaipongan adalah terletak pada gendingnya. Gending bukan hanya sekedar penunjang tarian tetapi merupakan salah satu aspek yang dapat menandakan identitas Jaipongan itu sendiri. Bahkan gending dapat dikatakan lebih dominan sebagai penanda atau ciri jaipongan, karena ketika suatu penampilan Jaipongan hanya menampilkan tariannya saja maka identitas Jaipongan tersebut menjadi tidak jelas. Sebaliknya, ketika Jaipongan disajikan gending saja, secara auditif Jaipongan akan tetap nampak.

Kelebihan lain dalam Jaipongan adalah warna tepak kendang yang bagitu variatif dan dinamis, sehingga merangsang orang yang mendengarkan untuk mengikuti irama kendang. Gugum mampu memadukan pola tepak kendang gaya Kaleran dan gaya Priangan (Bandung), yakni menggabungkan pola tepak teknik melem g-nya Priangan dan teknik pencug gaya Karawang dan Subang. Pengaruhnya pada pembawaan lagu yang dibawakan oleh pesinden sangat terasa pada cengkok lagu di akhir sebuah goongan, dalam hal ini Nano S 2007: 128) menjelaskan berikut.

"Bandung punya buntut dan Karawang menjadi buntet. Mengapa demikian, dengan teknik menabuh pelem, kendang lebih banyak mengatur tempo agar tetap ajeg melalui pukulan yang halus sehingga rasanya menjadi pelem (enak, gurih, nikmat). Ini akan mengantar sinden dalam membawakan lagu yang mengalun panjang, dan pada bagian akhir lagu walau sudah dibatasi dengan aksen tabuh gong besar suaranya masih berbuntut panjang, akan tetapi dalam Jaipongan dari hentakan kendang yang kadang lebih menggumuli lagu, pesinden menjadi agak terkekang temponya terutama pada bagian lagu yang mendekati jatuhnya gong, yang akhirnya menjadi buntet. Itulah sebabnya, yang menyebabkan Gugum dalam tari Jaipongnya cenderung memilih lagu-lagu yang berirama hiji setengah, dua wilet dan lalamba".

Pola irama itu embat-nya cenderung lambat, namun tepak kendangnya cenderung menghentakhentak, penuh energi. Volume dan aksen bunyi berlawanan dengan karakter tarian yang halus, apalagi dibungkus dengan tepak kendang yang bertenaga dan cenderung menghentak-hentak.
Karakternya tampak terasa muncul, bahkan tidak menganggu watak dan sifat tariannya. Gending Jaipongan sangat elastis dan terbuka untuk diterima oleh jenis kesenian tradisi apapun, seperti; wayang kulit, campur sari, atau pun musik Bali, termasuk dalam jenis yang bernuansa pop, jazz, dan seni modern lainnya.

Gamelan Jaipongan menggunakan gamelan lengkap, seperti Bonang, Saron, Demung, Peking, Rincik, Gong, Kempul, Kendang, dan Rebab, ditambah dengan kecrek. Pada awalnya laras yang digunakan adalah salendro, namun pada perkembangan lebih lanjut, terutama para kreator Jaipong setelah era Gugum Gumbira, ada yang menggunakan gamelan berlaras pelog.

Kalau dicermati secara seksama ada beberapa ciri yang membedakan antara menabuh pada gamelan Jaipongan dengan menabuh pada gamelan untuk tari lainnya, yaitu terletak pada tabuhan tiga waditra yang terdapat pada perangkat gamelannya, seperti: Kendang, Bonang, dan Kempul. Menurut Suwanda dan Dali (2008) motif-motif tepak kendang Jaipongan terinspirasi oleh idiom-idiom kesenian yang telah ada, seperti Kiliningan, Ketuk Tilu, Topeng Banjet, maupun Pencak Silat".

Kendang secara umum termasuk kepada waditra yang memainkan ritmis, berfungsi untuk mengatur irama dan tempo, serta sebagai aksentuasi atau penegas ritmegerak apabila gending yang disajikannya sebagai iringan tari. Dengan demikian permainan atau tabuhan Kendang sama sekali tidak berpengaruh kepada aspek nada dan melodi dari lagu yang disajikan. Artinya, tabuhan Kendang tidak berkaitan dengan lagu apa yang disajikannya, tetapi hanya berkaitan dengan irama dalam lagu yang disajikan. Bunyi Kendang Sunda memiliki beberapa ketentuan yang berkaitan dengan pengaturan nada. Frekuensi bunyi kendang disesuaikan dengan frekuensi nada-nada tertentu yang terdapat pada waditra gamelan pengiringnya walaupun tidak disusun menjadi sebuah laras.

Berangkat dari pernyataan di atas, waditra (instrumen) kendang yang akan dimainkan harus disesuaikan terlebih dahulu dengan waditra atau nada-nada tertentuagarsuarakendangyang muncul selaras dengan gamelan yang mengiringinya. Lili Suparli (2008) menjelaskan bahwa ada lima ketentuan atau lima cara steman kendang yang biasa digunakan oleh para pengendang Sunda yaitu, steman kendang pola 1, 2, 3, 4, 5. Kendang 
Jaipongan termasuk pada larasan pola 5 yaitu: Muka kendang kutiplak (muka kendang kecil atau anak bagian atas) di-stem pada nada Singgul (5/la) oktav tinggi (sama dengan nada singgul Alit $(5 / l a)$ pada waditra saron) laras salendro. Muka kendang kemprang/congo (muka kendang besar atau indung bagian atas), di-stem pada nada panelu (3/na) atau loloran (2/mi) oktav standar (sama dengan nada loloran (2/mi) atau panelu (3/na) pada waditra saron) laras salendro. Muka kendang katipung/ kentrung (muka kendang kecil atau anak), distem pada nada galimer (4/ti) oktav standar (sama dengan nada galimer (4/ti) pada waditra saron) laras salendro. Muka kendang gedug (muka kendang besar atau indung bagian bawah) oleh para pengendang biasanya distem atau disesuaikan dengan nada galimer (4/ti) laras salendro.

Selain digunakan untuk mengiringi gending Jaipongan, larasan kendang pola 5 juga digunakan untuk mengiringi Wayang Golek. Untuk memunculkan bunyi yang ideal pada steman kendang pola 5 ditentukan oleh ukuran kendang yang khusus, yaitu ukuran kendang besar dengan panjang antara $65 \mathrm{~cm}$ sampai $70 \mathrm{~cm}$ dengan diameter muka gedug (muka kendang bagian bawah) $35 \mathrm{~cm}$ sampai 40 $\mathrm{cm}$, dan muka kemprang/congo (muka kendang bagian atas) berdiameter antara $20 \mathrm{~cm}$ sampai $25 \mathrm{~cm}$, sedangkan ukuran kulanter (kendang kecil atau anak) yang biasa dipergunakan untuk kutiplak (muka bagian atas), dan katipung (muka bagian bawah) panjangnya antara $35 \mathrm{~cm}$ sampai $40 \mathrm{~cm}$, dengan diameter muka kutiplak (muka bagian atas) antara $12 \mathrm{~cm}$ sampai $15 \mathrm{~cm}$, dan muka katipung (muka bagian bawah) berdiameter antara $18 \mathrm{~cm}$ sampai $20 \mathrm{~cm}$.

Steman bunyi kendang dan ukuran kendang Jaipongan memiliki ketentuan khusus yang berbeda dengan steman dan ukuran kendang lainnya. Perbedaan tersebut memunculkan bunyi kendang yang berbeda dan khas. Dilihat dari ukuran frekuensi bunyi dalam kendang Jaipongan, terutama kemprang/congo (muka kendang besar atau indung bagian atas), memiliki frekuensi bunyi yang sama dengan frekuensi bunyi kemprang/ congo (muka kendang besar atau indung bagian atas) kendang Penca, yaitu memunculkan bunyi yang berfrekuensi tinggi. Pada perkembangan selanjutnya frekuensi bunyi kemprang (muka bagian atas) kendang Jaipongan oleh para pengendang disesuaikan dengan nada Galimer (4/



Gambar 6. Perangkat kendang Sunda (Foto: Koleksi Lili Suparli, 2009)

ti) oktav tinggi (sama dengan nada Galimer (4/ti) pada waditra peking).

Frekuensi di atas didasari oleh kebutuhan estetika tabuhan kendang Jaipongan yang disesuaikan dengan fungsi utama tabuhan kendang, yaitu mengatur tempo, dinamika dan mempertegas aksentuasi gerak tari. Oleh karena itu bunyi kendang yang telah diatur seperti di atas dipadukan pula dengan pola-pola ritme yang dibutuhkan untuk mengisi ritme gerak tari. Menurut Lili Suparli (2008) perpaduan itulah yang kemudian menjadi sebuah estetika garap kendang jaipongan, yang selanjutnya disebut dengan Tepak Kendang Jaipongan, sebagai kreativitas baru dalam garap kendang Sunda".

Munculnya motif tepak kendang Jaipongan tersebut terinspirasi dan digali dari keseniankesenian yang telah ada, untuk hal ini Suwanda dan Dali (seperti yang dituturkan kepada Gugum Gumbira) mengatakan, bahwa motif-motif tepak kendang Jaipongan terinspirasi oleh idiom-idiom kesenian yang telah ada, seperti Kiliningan, Ketuk Tilu, Topeng Banjet, maupun Pencak Silat.

Bonang adalah salah satu waditra yang terdapat pada seperangkat gamelan, baik yang berlaras salendro maupun laras pelog. Cara memainkan atau motif tabuhan yang biasa dimainkannya adalah dikemprang, digumek, dan lain-lain. Meskipun cara memainkannya berbeda atau tidak sama seperti alat lainnya. Kehadiran bonang menjadi satu komposisi yang padu dalam pertunjukannya seperti dikemukakan Nano. S (2006: 96) berikut.

Lagam gending (style) antar waditra gamelan menjadi satu komposisi yang padu dalam pagelarannya. Lagam-lagam itu mempunyai motif tabuh secara tersendiri yang berlainan dengan waditra lain, seperti 
yang terjadi di wilayah Pasundan bahwa dalam teknik menabuh bonang dan rincik pada gamelan Sunda bermacam-macam tabuh, di antaranya dicaruk, dikempyang, dipancer, digumek, dicacag, dan lainnya.

Namun demikian dalam gending Jaipongan, tabuhan bonang memunculkan tabuhan khusus yang mengadopsi dari tabuhan ketuk pada pertunjukan Ketuk Tilu dan pertunjukan Topeng Banjet, sedangkan alat yang dipergunakannya hanya tiga buah, yaitu nada 5 (la alit), 3 (na) 2 (mi). Walaupun terdapat motif tabuhan dikemprang tetapi tabuhan tersebut hanya dipergunakan pada bagian gelenyu atau pangjadi (bagian lagu awal sebelum masuk pada lagu pokok). Untuk mengiringi lagu pokok biasanya tabuhan bonang dicacag, sehingga tabuhan bonang tersebut bisa dikatakan ciri dari gending Jaipongan.

Kehadiran (bunyi atau tabuhan) kempul atau goong kecil dalam pertunjukan Jaipongan menjadi salah satu yang dominan, bahkan hampir sama dominannya dengan tabuhan bonang maupun tabuhan kendang. Menurut Suparli (2008) permainan kempul dalam Jaipongan selain sebagai penanda irama yang dimainkan, juga berfungsi sebagai aksen dari ritme tabuhan kendang. Artinya, bunyi atau tabuhan kempul dalam Jaipongan sangat berbeda dengan tabuhan-tabuhan dalam pertunjukan lainnya. Pada tarian Keurseus, Topeng, Wayang, Kreasi Baru, misalnya, fungsi bunyi kempul hanya penanda irama, tetapi dalam Jaipongan bunyi atau tabuhan kempulselain sebagai penanda irama juga berfungsi sebagai aksen dari ritme bunyi kendang. Bahkan Gugum Gumbira (2008) menambahkan bahwa motif atau tabuhan kempul dalam Jaipongan terilhami oleh permainan bass gitar dalam pertunjukan musik'. Hal ini mengakibatkan irama dalam Jaipongan menjadi dinamis (selain tabuhan kendang dan bonang) dengan motif tabuhan kempulnya, di samping itu dipertegas pula oleh bunyi kecrek. Dengan demikian para penata gending yang dipercaya oleh Gugum telah mampu menghasilkan karya baru dengan warna yang begitu spesifik, dalam arti sangat berbeda dengan pola gending tari rakyat sebelumnya yang pada gilirannya mewarnai pola irama gending atau karawitan Sunda lainnya.

\section{Tata Busana Tari}

Busana tari Jaipongan tampak memancarkan warna baru, yang bahan dasarnya diangkat dari busana masyarakat pahumaan, yakni kabaya dan sinjang bagi wanita. Biasanya apabila kaum wanita memakai sinjang dan kabaya bergerak pelan dan penuh ke hati-hatian, ini disebabkan oleh terbatasnya ruang gerak karena bagian bawah mengekang keleluasan bergerak. Busana kabaya dan sinjang dalam tari Jaipongan memberikan keleluasaan untuk bergerak, karena pola busananya didesain dengan tidak menutup ruang gerak.

Terlebih pada busana penari wanita, merupakan pengembangan dari busana pesinden Kliningan Bajidoran baik dari sisi bentuk maupun warnanya yang oleh Gugum Gumbira diberi warna lain serta aksen melalui pengayaan ornamen. Hasilnya adalah munculnya busana berkarakter yang sesuai dengan jiwa tarian, dan sekaligus memberikan kesan jati diri kasundaan. Menurut Soejanto Poespo Wardojo (1986: 30), pola pengembangan busana seperti yang dilakukan oleh Gugum Gumbira pada tari Jaipongan masih memperlihatkan lokal genius, yaitu adanya unsurunsur atau ciri-ciri tradisional yang mampu bertahan, bahkan memiliki kemampuan untuk mengakomodasi unsur-unsur budaya dari luar serta mengintegrasikannya dalam kebudayaan asli. Namun demikian, dalam perkembangannya busana Jaipongan mengalami perubahan sesuai kebutuhan repertoar tari yang diciptakan Gugum Gumbira. Hal ini terlihat, terutama repertoar tari Sonteng, Rawayan, dan Kawung Anten.

\section{Penutup}

Jaipongan yang diciptakan Gugum Gumbira merupakan hasil upaya kreatif yang dilandasi oleh pemahamannya terhadap berbagai tatanan nilai kearifan lokal tradisi masyarakat Sunda, dan meramunya dalam cita rasa masyarakat kota/ urban. Sikap kritis Gugum terhadap karya-karya tari Sunda sebelumnya menghasilkan kinestetika tari baru dalam perkembangan seni pertunjukan tari Sunda karena lebih merupakan sebuah proses pencarian makna keindahan baru atau dekonstruksi kinestetika tari Sunda yang selama ini berlatar budaya priyayilmenak. 
Latar budaya yang menekankan pada tatanan nilai etika dan estetika tari egaliter yang khas, yaitu menghasilkan sebuah konstruksi tari pada Jaipongan dengan struktur tari yang simpel, dinamis, enerjik, dan maskulin. Begitu pula dengan kehadiran unsur lain yang menjadi bagian integral dalam Jaipongan, seperti iringan tari, tata busana, dan artistik lainnya. Konstrukti tari seperti itu telah menjadi identitas baru tari Sunda bagi masyarakat Jawa Barat hingga saat ini. Itu berarti bahwa melalui Jaipongan, Gugum Gumbira telah mampu membangun dinamika kehidupan seni pertunjukan tari Sunda. Oleh karena itu, dalam perkembangan seni pertunjukan tari Sunda, Jaipongan dan Gugum Gumbira Tirasondjaya sebagai penciptanya selayaknya diposisikan sebagai sebuah genre tari dan seniman pembaharu generasi ketiga.

\section{Kepustakaan}

Caturwati, Endang. 2006. Perempuan \& Ronggeng Di Tatar Sunda: Telaahan Sejarah Budaya. Bandung: Pusat Kajian LBPB.

Mulyana, Edi, dan Lalan Ramlan. 2012. Tari Jaipongan. Bandung: Jurusan Tari STSI Bandung.

2012. "Keser Bojong: Idealisasi Pencitraan Jaipongan Karya Gugum Gumbira” dalam Jurnal Seni dan Budaya PANGGUNG. Vol. 22 No. 1. Januari-Maret 2012, 37-51.

Nano, S., 2007, "Nang Neng Nong ... Jaipongan" dalam Endang Caturwati dan Lalan Ramlan
(Eds.) Gugum Gumbira: Dari ChaCha ke Jaipongan. Bandung: Sunan Ambu Press: 123-132.

Poespo Wardojo, Soejanto. 1986. Pengertian Local Genius dan Relevansinya dalam Modernisasi. Jakarta: Pustaka Jaya.

Ramlan, Lalan. 2008. Tayub Cirebonan: Artefak Budaya Masyarakat Priyayi. Bandung: Sunan Ambu Press.

Rohidi, Tjetjep Rohendi. 2011. Metodologi Penelitian Seni. Semarang: Cipta Prima Nusantara.

Sumardjo, Jakob. 2000. Filsafat Seni. Bandung: ITB. 2003. Simbol-Simbol Artefak Budaya Sunda. Bandung: Kelir. 2006. Estetika Paradok. Bandung: Sunan Ambu Press.

R.M. Soedarsono. 1999. Metodologi Penelitian Seni Pertunjukan dan Seni Rupa. Bandung: MSPI.

\section{Informan}

Askin (78 th.) Seniman Gokgik. Tinggal di Karawang.

Euis Komariah (65 th). Istri Gugum Gumbira. Tinggal di Jalan Kopo, 17 Bandung

Gugum Gumbira (68 th.). Seniman. Tinggal di Jalan Kopo, 17 Bandung.

Lili Suparli (46 th.). Seniman dan akademisi Karawitan. 